\title{
Eightieth year of Peking Man: Current status of Peking Man and the Zhoukoudian site
}

\author{
Qian Wang ${ }^{1,2}$, Li Sun ${ }^{2}$ \\ ${ }^{1}$ Department of Anatomical Sciences, University of the Witwatersrand, 7 York Rd., \\ Parktown 2193, South Africa, E-mail: 055qwang@chiron.wits.ac.za \\ ${ }^{2}$ Institute of Vertebrate Paleontology and Paleoanthropology, \\ Chinese Academy of Sciences, P.O. Box 643, 100044 Beijing, China
}

\begin{abstract}
The current status of and recent developments around Peking Man and Zhoukoudian are reviewed. The taxonomic status, phylogenetic position, cultural attributes and taphonomy of Peking Man are in question, and a new chronological frame for the Zhoukoudian site is emerging. Post-war excavation, current Peking Man specimens, the research unit, personalities, commemoration, and classic books are introduced, with special reference to the search for the long-missing Peking Man fossils.
\end{abstract}

KEY WORDS Peking Man, Zhoukoudian, Homo erectus, "Sinanthropus"

Prz. Antropol. - Anthropol. Rev. (2000), vol. 63, pp. 19-30, ISBN 83-86969-60-1, ISSN

0033-2003

\author{
Anniversaries are not only times for looking back at the past \\ Nor for appraising where we stand at the present. \\ They are times for looking forward. \\ Phillip V. Tobias, 1997
}

The excavation of the Peking Man site at Zhoukoudian disclosed the antiquity of humankind in China, and revolutionized people's perception of his long past. The events, such as the legendary start, the epic excavation, amazing discoveries, the mysterious disappearance, the hunt for the missing fossils, together with colorful personalities associated with prehistoric Peking Man at Zhoukoudian have constituted a classic chapter in paleoanthropology of the $20^{\text {th }}$ century. It is a story full of hope, serendipity, sensation, mystery and tragedy.
It was in the summer of 1921, when Johan G. Anderson, a Swedish geologist, picked up a quartz fragment from cave deposits at a small hill at Zhoukoudian (formerly Chou-kou-tien), the Peking Man site of today [ANDERSON 1934]. That began the Peking Man saga. This year marks the $80^{\text {th }}$ year of Peking Man. In fact, also in 1921, Otto Zdansky dug at Zhoukoudian and found the first Peking Man specimen, an isolated tooth, that he did not announce until years later [BLACK 1926; ZDANSKY 1927]. Thus, on 
the occasion of the $80^{\text {th }}$ year of Peking Man, it is interesting to reflect on how ideas have changed to and what has developed in relation to Peking Man and Zhoukoudian.

\section{The name: from Homo erectus to Homo uncertain}

Although Zdansky identified human characters in the first two teeth of the Peking Man fossils, he preferred to label them "?Homo sp." (with a question mark), meaning an "uncertain" human [ZDANSKY 1927]. Then, based on the third tooth unearthed by Berger Bohlin, Davidson BLACK [1927] observed a number of interesting and unique characters and named a new genus and species for the primitive human that once lived near Peking, Sinanthropus pekinensis, meaning "Chinese Man of Peking". From then on, it was popularly called Peking Man. The emergence of the first complete skullcap of Peking Man, discovered by W. C. Pei in 1929, quited the harsh criticism to Black's interpretation based on a single tooth, and the resemblance between $S$. pekinensis and Pithecanthropus erectus, which Eugene DUBOIS [1894] found in Java in 1891, conclusively vindicating the human nature of the latter. Ironically, the striking resemblance between the two Eastern Asian hominid clans had led scholars repeatedly to lump them together or to let Peking Man sink into Pithecanthropus [ZUCKERMAN 1933; BOULE 1937; KOENIGSWALD \& WEIDENREICH 1939]. In 1940 Weidenreich proposed Homo erectus as a taxon to include both Pithecanthropus erectus and Sinanthropus pekinensis. H. erectus was ultimately universally accepted in the 1950s after MAYR [1951] supported the "lumping" trend. From then on,
Homo erectus became Peking Man's scientific name. Recently, however, it was argued by some anthropologists that there is no distinct or valid demarcation between $H$. erectus and $H$. sapiens, so they should be lumped into the evolutionary species - Homo sapiens [WOLPOFF et al. 1994; WOLPOFF 1996]. But from a cladistic point of view, $H$. erectus is a valid species of Eastern Asia [ANDREWS 1984]. Although there is still no consensus on how Peking Man should be named, "Peking Man", as the common name, has survived. One can even find "Peking Man" in an English-Chinese dictionary.

\section{Phylogenetic position: from missing link to cul-de-sac?}

The phylogenetic position of $H$. erectus is the basic point of divergence of two opposing hypotheses of the origin of modern humans, the "Multiregional model" and the "Out-of-Africa" concept. At first, Peking Man was perceived as the missing link between apes and humans. BLACK [1926: p. 734] initially concluded that "the Chou K'ou Tien discovery therefore furnishes one more link in the already strong chain of evidence supporting the hypothesis of the central Asiatic origin of the Hominidae". Peking Man then inevitably helped to eclipse the real missing link, Dart's Australopithecus, for at least two decades [TOBIAS et al. 2000]. As the first recognized early primitive hominid in Mainland Asia, Peking Man was a logical ancestor of modern humans in Eastern Asia. WEIDENREICH [1943] observed some common features shared by Peking Man and modern Mongoloids, such as the low and flat face, high frequency of the Inca bone, shovel-shaped incisors, and he 
believed that Peking Man was ancestral to modern Chinese. He also hypothesized that there had been continuity in human evolution in China since Peking Man. Confirmation of this hypothesis has become one of the chief objects of Chinese prehistoric research. After the universal recognition of Australopithecus and then $H$. habilis, and the shift of the perceived cradle of humankind from Asia to Africa, this situation has changed considerably. As FRANZEN [1994] pointed out, $H$. erectus "is still considered a fossil human being, not one situated somewhere near ape-like ancestors of Man, but very close already to Homo sapiens, so close that it seems almost to amalgamate with it". The proponents of Multiregional origins of modern humans stressed the ancestordescendant relationship between $H$. erectus and $H$. sapiens [WOLPOFF et al. 1984, 1994; WOLPOFF 1996; WU 1990; WU \& POIRIER 1995]. However, when invoking cladistic analysis, some scholars proposed to exclude $H$. erectus from being ancestral to modern $H$. sapiens, and regarded it as a dead end, or cul-desac [ANDREWS 1984; STRINGER 1984]; thus, Peking Man is neither a missing link nor an ancestor. Besides, genetic analyses of both modern people around the world [CANN et al. 1987], and people of different ethnic groups in China [CHU et al. 1998] suggest that modern Chinese have a very recent beginning thus providing the Out-of-Africa theory with strong support. On the other hand, accumulating osteological and paleolithic cultural evidence in China strongly supports the regional continuity model of human evolution and consequently the Multiregional origins of modern humans [WU R. 1986; WU X. 1990; WU \& POIRIER 1995; LING 1996; ZHANG 1999;
WANG \& TOBIAS 2000a]. The question as to whether Peking Man is a link to modern humans or a link to nowhere, remains, and it seems there is no answer to this puzzle of pre-paradigm in sight [ŠTRKALJ 2000].

\section{Family: from Beijing (Peking) to Nanjing}

The Peking Man-like human remains, including a skull found in Hexian, Anhui Province in 1981 [WU \& DONG 1982], cranial fragments from Yiyuan, Shangdong Province in 1981 [XU 1986], and two skulls from Tangshan (Nanjing), Jiangsu Province in 1993 [LU 1996], suggest that the family of Peking Man was widespread throughout areas from northern China to the territory across the Yangtze River during the Middle Pleistocene [WANG \& TOBIAS 2000b]. The Tangshan (Nanjing) skull No. I even provides an almost complete left face (the first intact face of $H$. erectus found in China), which enables us to know what Peking Man looked like [WANG \& TOBIAS 2000a].

\section{Date: a suppressed chronological frame}

The level of the cave deposits at Zhoukoudian containing the fossil teeth was initially estimated to be Late Tertiary or Early Quaternary, and thus BLACK [1926] called Peking Man a "Tertiary Man"! A reliable numerical time scale did not emerge until the 1960s when several techniques, including U-series disequilibrium, fission track, paleomagnetism, thermoluminescence and amino acid racemization, were conducted during a multidisciplinary research project. From then on, Peking Man was generally accepted to have lived from 460,000 to 230,000 years B.P. [WU et al. 1985]. 
Together with the morphological features of Peking Man, the date of Zhoukoudian plays a pivotal role in the assignment and dating of other human fossils found in China. However, the apparent coexistence of $H$. erectus and early $H$. sapiens, and the ensuing confusion on how to interpret this phenomenon, led people to cast doubt on the authenticity of these accepted dates of Peking Man [CHEN \& ZHANG 1991]. Recent attempts to reanalyze the age of Zhoukoudian deposits have disclosed that the currently accepted chronological frame was a result of compression. The new age by U-series technique of speleothem in Layer 3 at Peking Man site Locality 1, where the youngest and also the most advanced specimen of Peking Man, skull $\mathrm{V}$, was found, showed that the latest observed Peking Man to be older than 400,000 years B.P., while the earliest was probably over 800,000 years B.P. [SHEN \& JIN 1991; SHEN in press]. If these new dates are validated, then the duration of human occupation at Zhoukoudian, the evolutionary process of humankind in China, and other time-related aspects should be reconsidered.

\section{Reconstruction: from female to male}

As the face, as a whole, seems to have been too fragile to be totally preserved over half million years owing to taphonomical reasons, the key problem in the reconstruction of Peking Man is to rebuild topographically the facial architecture and then to combine it with one of the current six relatively complete skullcaps. Many people have done such work over the past sixty years in various museums or relevant units, but few have publicised their results. The most popular study is one of the skull of a female Pe- king Man reconstructed by Weidenreich and Swan [WEIDENREICH 1943]. The face is low and flat with middle facial flexion, and the antero-lateral surface of the frontal process of the zygomatic bone faces forward. These features taken together show a general modern Mongoloid-like face. Yet there are some flaws due to the artificial combination of a female cranial cap (skull XI or LII) while a male maxillary bone No. V, even though it was mentioned that maxillary bone No. II was chosen in the reconstruction. So, the zygomatic bone had to be turned to some degree to make contact with the maxillary and the frontal bones. This mismatch results in a narrowing of the mid-face, arching of the supra-orbital torus, reshaping of the orbit, a lowering of the horizontal position of the zygomatic arch and a protrusion of the lower face, and so on [WANG 1999]. However, these flaws induced by incompleteness of the fossils used do not affect its authoritative status: the partial face attached to Tangshan (Nanjing) skull I confirms its basic morphologic and topographic pattern [WANG \& TOBIAS 2000a]. TATTERSALL \& SAWYER [1996] made a new reconstruction based on restored casts. They gave Peking Man a new face: male this time. This face is narrow and high and is in harmony with the skull. However, it also shows some features usually detected in Afro-European Middle Pleistocene hominids, e.g., the antero-lateral surface of the frontal process of the zygomatic bones faces more laterally, and the degree of facial flatness is low. These together make this male face topographically different from those of $H$. erectus in East Asia to some extent [WANG 1999]. The very impressive prehistoric Peking Man couple (Weidenreich 
\& Swan's woman, and Tattersall \& Sawyer's man), appear on the cover of M.H. Wolpoff's magnum opus, Human Evolution (1996-1997 edition) [WOLPOFF 1996].

\section{Taphonomy: cave home to Peking Man or hyenas?}

As abundant human fossils, artifacts, animal fossils, and ash residues are usually considered convincing evidence of occupation of hunter-gatherers, Zhoukoudian has long been accepted logically as the cave home of Peking Man [CHIA 1975]. However, BINFORD \& HO [1985] proposed that all bones, including the human remains, were brought in by hyenas and other carnivores. Thus, Peking Man was only a victim of carnivores, and Zhoukoudian was a cave home to carnivores rather than to Peking Man. This was echoed by WEINER et al. [1998], when they dealt with the issue of fire use (see below). In fact, there are 5 layers (No. 13, 10, 8-9, and 6) containing hyena coprolites, indicating that hyenas repeatedly used the cave as a den. Perhaps the Zhoukoudian cave at different times served as home to Peking Man and to hyenas. The finding that all skullcaps of Peking Man were baseless, and that relatively few post-cranial skeletons were found in the cave, led WEIDENREICH [1943] to propose that the individuals represented by the fossils were victims of Peking Man living at the Zhoukoudian cave. They were consumed like other game. On this view Peking Man was a cannibal. The loss of almost all Peking Man skulls makes it impossible to scan them with state-of-the-art technology in order to clarify whether the human remains were accumulated by either carnivores or cannibals.

\section{Peking Man the fire user}

One of Peking Man's most amazing attributes is his use of fire [BLACK 1931]. Piles of ashes with abundant burnt: soil, bones and seeds, as well as scorched stones found in situ at Zhoukoudian (Locality 1 and 15) provide conclusive evidence of fire use and control by Peking Man. Apparently, Peking Man used fire to cook, illuminate, warm himself and keep wild beasts away. Thick ash piles also reflect that Peking Man could sustain fire for quite a long time. Peking Man might have collected fire from a natural bush or prairie fire. However, the issue of fire use at Zhoukoudian was challenged in 1998. The ash residues were reintepreted as accumulations of organic material laid down under water. Therefore Peking Man's capacity to control and use fire was denied, and it was questioned anew whether Zhoukoudian was a home site of Peking Man or not [WEINER et al. 1998]. However, this sensational claim failed to convince the majority in the prehistoric field. The ensuing rebuttal and heated discussion at the meeting in October 1999 on the occasion of the commemoration of the discovery of the first skull of Peking Man led to Peking Man's use of fire use being favored again [WU 1999; WEINER et al. 1999].

\section{Searching for missing Peking Man specimens}

Peking Man was accepted, although only temporarily, as the "Missing Link". Unfortunately, the missing link went missing again. The Peking Man fossils found at Zhoukoudian in the period between 1927 and 1937 mysteriously disappeared during the Japanese invasion of 
China in 1941 . The $80^{\text {th }}$ year of Peking Man also marks the $60^{\text {th }}$ year of the disappearance of pre-war Peking Man specimens. Five skulls, 16 cranial fragments, 16 facial fragments, 14 mandibles, 147 teeth (64 isolated, including the type specimen of Sinanthropus pekinensis, and others attached to jaws), 7 femora, 2 humeri, 1 clavicle and 1 lunate constitute an inventory of the "missing bones". Only high quality casts of these missing specimens survived. Weidenreich had systematically described the entire set of Peking Man remains found at Zhoukoudian before the War. His comprehensive work on Peking Man [WEIDENREICH 1936a,b, 1937, 1941, 1943], together with BLACK's [1927, 1929, 1930a,b] contribution, became particularly valuable after the loss of the original Peking Man fossils.

Soon after the surrender of Japan, the Chinese Government requested the Allied Army to aid the search for the missing Peking Man specimens in Tokyo. But the search was in vain (although some non-hominid ZKD fossils were found in Japan), as was true of subsequent attempts. From then on, much information and many clues streamed into the IVPP (today's Zhoukoudian team, see below), openly or secretly, obtrusively or unobtrusively, but without any substantial consequence. Parts of the searching activities were recorded in several books, such as: Peking Man [SHAPIRO 1974]; The Search for Peking Man [JANUS \& BRASHER 1975]; and The Story of Peking Man [JIA \& HUANG 1990]. In 1999, L. Jia (formerly L.P. Chia), a veteran of Zhoukoudian, launched a new search for the long missing Peking Man fossils, code-named "Search at end of the century", which is currently continuing. No one seems to know where the fossils are. As time passes, the search for the missing Peking Man fossils is probably becoming a mission impossible. However, it continues. Searching for the missing Peking Man specimens will be more a rite than a reality. It is salutary to remember how modern humans sinned against their ancestors through such an attempt.

\section{Post-war excavations and current Peking Man specimens}

Fieldwork at Zhoukoudian resumed in 1949, and took place again in 1951, 1958-1960, 1966 and 1978-1981. A handful of human fossils were found during these excavations. Below is an inventory of current Peking Man specimens housed at the University of Uppsala (pre-war specimens), and the Institute of Vertebrate Paleontology and Paleoanthropology (post-war specimens).

Uppsala University of Sweden - 3 isolated teeth held at Uppsala since 1923 [BLACK 1926; ZDANSKY 1927, 1952]:

Left lower P3 (1921)

Right upper M3 (1923)

Right lower P4 (1950, recognized in lab from Zdansky's 1920s ZKD collection).

$I V P P-6$ isolated teeth, 1 mandible with a tooth, 2 cranial fragments, 2 fragmentary long bones, found or identified since 1949 [WOO \& CHIA 1954, WOO \& CHAO 1959, CHIU et al. 1973]:

Left upper I1, left lower M1, left lower M2 (1949)

Right upper P3 (1951)

Lower middle part of a tibia (1951, recognized in lab from pre-war collection)

Small fragment of middle part of right femoral shaft (1951, recognized in lab from pre-war collection) 
Mandible (body), with a left M1 (1959)

Right lower P3 (1966)

Frontal and occipital fragments of skull $\mathrm{V}$ or $\mathrm{H}$ (1966): the two fragments fit well with the parietal and temporal parts of both sides found before the war (only casts left) and together constitute an almost complete skullcap. It is the 6th skullcap of Peking Man, coming from Layer 3.

\section{Potential cave deposits}

It was long estimated that at least one third of the total cave deposits at Zhoukoudian was untouched, which allowed hope for the recovery of more Peking Man fossils. That was confirmed in 1996 [WANG \& TOBIAS 2000b], when engineers from Electricité de France (EDF) employed an electro-magnetic method to explore the whole hill where Locality 1 , the major Peking Man site, and other adjacent sites are scattered, and detected many potential Pleistocene deposits, which probably connect all the sites through an underground cave system. The investigation was initiated by Prof. Yves Coppens. UNESCO and EDF submitted the formal report of results of this new Zhoukoudian investigation to the Chinese government in November 1998. Thus it seems that a new round of excavation is in sight.

\section{Zhoukoudian, the Peking Man site: from mausoleum to monument}

The cradle of Chinese prehistoric research, Zhoukoudian, the Peking Man site, is located at the foot of the Western Mountain, $50 \mathrm{kms}$ southwest of Beijing. The pre- and post-war discoveries of human fossils, together with abundant mammal fossils, artefacts, ash residues and other remains, make the Zhoukoudian the largest single seedbed of
$H$. erectus in the world both then and now. In 1960, the State Council of China proclaimed the Peking Man site as a national monument. In 1989, UNESCO formally placed it on the World Heritage List in view of its unique value in illustrating prehistoric human society and the process of human evolution in East Asia. Today, the Zhoukoudian site is frequented by scholars of prehistory and prehistory-minded tourists from all over the world.

\section{Zhoukoudian team: from CRL to IVPP}

The Cenozoic Research Laboratory (CRL) within the Peking Union Medical School and the National Geological Survey of China, set up in 1929 by Davidson Black and other colleagues, based on the Zhoukoudian team, was the initial prehistoric research unit in China. Scholars from seven countries once worked at the CRL before the War and set up an excellent example of international cooperation. Now the CRL has grown and become the Institute of Vertebrate Paleontology and Paleoanthropology (IVPP) within the Chinese Academy of Sciences. The IVPP is one of the top seven paleoanthropological research units in the world and also one of the most prestigious paleontological research units. Many international paleoanthropologists, paleolithic archaeologists and paleontologists have visited it one or more times and some have conducted or are conducting joint projects with Chinese scholars. Almost all the prehistoric research work in China is based at the IVPP. Since Zhoukoudian was discovered, over one thousand prehistoric sites have been recognized in China, among them nearly seventy sites that have yielded human fossils. 


\section{Commemoration}

The excavation and research at Zhoukoudian entitles the pioneer scholars, including Johan Anderson, Otto Zdansky, Berger Bohlin, Davidson Black, Franz Weidenreich, Pierre Teihard de Chardin, Wen Chung Pei, and others, to be enshrined in the Pantheon of paleoanthropology. They, together with Lanpo Jia (still alive and active) are collectively honored as the founders of prehistoric research in China. There are also a number of anniversaries associated with $\mathrm{Pe}$ king Man and personalities mentioned above. The most important is the discovery of the first skull of Peking Man by W. C. Pei on 2 December 1929. A periodical paleoanthropological symposium to commemorate the historic event has been organized in the IVPP every five years since 1954. The last one took place in 1999 on the occasion of its $70^{\text {th }}$ anniversary. This international gathering is also one of many current prestigious regular international gatherings in the prehistoric field, offering a good opportunity for better communicating among world scholars in paleoanthropology and for a better understanding of the Chinese data.

\section{Classic books}

Two books (in English) are essential to the understanding of the Peking Man saga. One of them is JIA \& HUANG'S [1990] The Story of Peking Man. It is currently the most authoritative account of the history of Zhoukoudian and Peking Man, for it is based on first hand material. Jia was a veteran at Zhoukoudian and led the excavation from 1934 to 1937 until it was stopped by the War. He discovered three skulls of Peking Man in 11 days in 1936, which made sensational news in the scientific world after Pei's find in 1929. Huang was director of Zhoukoudian field station in the 1960s70 s. On the $70^{\text {th }}$ anniversary of the discovery of the first skull of Peking Man, another book, The Chronicle of Zhoukoudian (1927-1937), edited by JIA [1999], was published. It is in fact an album, containing hundreds of valuable old photographs of excavation, discoveries, personalities, historic events, and so on, with legends in English. It is best to read the two books concurrently. Together they weave a vivid legend of human history in words and pictures.

\section{Peking Man in the Internet}

The internet greatly improves the transmission of knowledge. Peking Man and Zhoukoudian are taking advantage of this too. There is a special web site $<$ www.peking-man.org.cn> (in Chinese; no web site in English exists to date) and relevant web pages, almost 500 in number of "Zhoukoudian" and over 11,000 of "Peking Man"(figures in the internet at the end of October 2000) are together introducing the history, discoveries, personalities, reinterpretations, and releasing news and advances around Peking Man and the Zhoukoudian site.

\section{Peking Man in $21^{\text {st }}$ century}

Peking Man remains as one of the most important paleoanthropological discoveries of the $20^{\text {th }}$ century. For Peking Man, time is fossilized too. For people of modern times, knowledge and perspectives constantly change. In the $21^{\text {st }}$ century, we will continue to remember Peking Man, study it, debate it, search for it and review it. The Peking Man saga continues. 


\section{Acknowledgements}

We sincerely thank the Institute of Vertebrate Paleontology and Paleoanthropology (IVPP), and the Department of Anatomical Sciences, University of the Witwatersrand, Johannesburg, for support. We also thank the National Research Foundation of South Africa for financial aid. We are grateful to Professor Phillip V. Tobias, Dr Katarzyna A. Kaszycka, Dr Goran Štrkalj, Mr. David J. Chorn, and Mrs. Heather White for their invaluable assistance and encouragement.

\section{References}

ANDREWS P., 1984, An alternative interpretation of the characters used to define Homo erectus, Courier Forschungs-Institut Senckenberg, 69, 167-175

ANDERSON J.G., 1934, Children of the yellow earth: studies in prehistoric China, Kegan Paul, Trench, Trubner \& Co., London

BINFORD L.R., C.K Ho,1985, Taphonomy at a distance: Zhoukoudian, the "cave home of Beijing Man?", Curr. Anthrop., 26, 413-442

Black D., 1926, Tertiary man in Asia: the Chou Kou Tien discovery, Nature, 118, 733-734

BlaCK D.,1927, On a lower molar hominid tooth from the Chou Kou Tien deposit, Palaeontologia Sinica, Series D, 7(1), 1-28

BLACK D.,1929, Sinanthropus pekinensis: the recovery of further fossil remains of this early hominid from the Chou Kou Tien deposit, Science, 69, 674-676

BLACK D., 1930a, Interim report on the skull of Sinanthropus, Bull. Geol. Soc. China, 9, 7-22

BLACK D., 1930b, Notice of recovery of a second adult Sinanthropus skull specimen, Bull. Geol. Soc. China, 9, 97-100

Black D., 1931, Evidences of the use of fire by Sinanthropus, Bull. Geol. Soc. China, 11, 107108

Boule M., 1937, Le Sinanhtrope, L'Anthropologie, 47, 1-22

CAnN R.L., M. Stoneking, A.C. Wilson, 1987, Mitochondrial DNA and human evolution, Nature, 325, 31-36
ChIA L.P., 1975, The cave home of Peking Man, Foreign Languages Press, Beijing

Chiu C.L., Y.M. GU, Y.Y. Zhang, S.S. Chang, 1973, Newly discovered Sinanthropus remains and stone artefacts at Choukoutien, Vertebrata PalAsiatica, 11, 109-131

Chen T., Y. Zhang, 1991, Paleolithic chronology and possible coexistence of Homo erectus and Homo sapiens in China, World Archaeology, 23, 147-154

Chu J.Y., W. Huang, S.Q. KuAng, J.M. Wang, et al., 1998, Genetics relationship of populations in China, Proc. Natl Acad. Sci. USA, 95, 11763-11768

DuBoIs E., 1894, Pithecanthropus erectus, Eine menschenahnliche ubergangsform aus Java, Landesdruckeri, Batavia

FrANZEN J.L., 1994, The Homo erectus problem. Courier Forschungs-Institut Senckenberg, 171, 9-10

JANUS C.G., W. BRASHER, 1975, The search for Peking Man, Macmillan Publishing Co., New York

JIA L.,1999, The chronicle of Zhoukoudian (19271937), Shanghai Scientific and Technical Publishers, Shanghai

JiA L., W. HuANG, 1990, The story of Peking Man, Foreign Languages Press, Beijing

Koenigswald G.H.R. von, F. WeIDEnReich, 1939, The relationship between Pithecanthropus and Sinanthropus, Nature, 144, 926-929

LING S., 1996,Comparison of technological mode of Paleolithic culture between China and the West, Acta Anthrop. Sinica, 15, 1-20

Lu Z., 1996, Human fossils, [in:] Nanjing hominid site, Nanjing Municipal Museum and Department of Archaeology of Peking University, Wenwu Press, Beijing, 15-82

MAYR E.,1951, Taxonomic categories in fossil hominids, Cold Spring Harbor Symposia on Quantitative Biology, 15, 109-118

PEI W.C.,1929, An account of the discovery of an adult Sinanthropus skull in the Chou Kou Tien deposit. Bull. Geol. Soc. China, 8, 203-250

ShaPIRO H.L.,1974, Peking Man, Simon and Schuster, New York

SHEN G., L. JIN, 1991, Restudy of the upper age limit of Beijing Man cave, Acta Anthrop. Sinica, 10, 273-277

SHEN G., (in press), Chronological position of New Cave site at Zhoukoudian, Int. J. Anthrop. 
Stringer C.B., 1984, The definition of Homo erectus and the existence of the species in Africa and Europe, Courier ForschungsInstitut Senckenberg, 69, 131-143

ŠTRKALJ G., 2000, The conflict of pre-paradigm schools in modern human origins research, Acta Biotheoretica, 48, 65-71

TATTERSall I., G.J. SAWYeR, 1996, The skull of "Sinanthropus" from Zhoukoudian, China: a new reconstruction, J. Hum. Evol., 31, 311-314

ToBIAS P.V., 1997, A septuagenarian looks at the septuagenary Wits Medical School, The Leech, 66, 3-17

Tobias P.V., Q. WANG, J.L. CoRmack, 2000, Davidson Black and Raymond A. Dart: AsianAfrican parallels in palaeo-anthropology, Acta Anthrop. Sinica, 19, (in press)

WANG Q.,1999,Comments on restoration of Peking Man's skull, [in:] Book of abstracts of the International Symposium on Palaeoanthropology in Commemoration of the $70^{\text {th }}$ Anniversary of the Discovery of the First Skull of Peking Man at Zhoukoudian, 12-16 October 1999, Beijing, 18

Wang Q., P.V. ToBias, 2000a, Review of the phylogenetic position of Chinese Homo erectus in light of midfacial morphology, Acta Anthrop. Sinica, 19, (in press)

Wang Q., P.V. ToBIAS, 2000b, Recent advances in Chinese palaeo-anthropology, S. Afr. J. Sci., 96, (in press)

WeIDENREICH F., 1936a, The mandibles of Sinanthropus pekinensis: a comparative study, Palaeontologia Sinica, Series D, 7(3), 1-162

WEIDENREICH F., 1936b, Observations on the form and proportions of the endocranial casts of Sinanthropus pekinensis, other hominids, and the great apes: a comparative study of brain size, Palaeontologia Sinica, Series D, 7(4), 1-50

WeIDENREICH F., 1937, The dentition of Sinanthropus pekinensis: a comparative odontography of the hominids, Palaeontologia Sinica, New Series D, 1, 1-180

WeidenReich F., 1940, Some problems dealing with ancient man, Am. Anthrop., 421, 375-383

WeIDENREICH F., 1941, The extremity bones of Sinanthropus pekinensis, Palaeontologia Sinica, New Series D, 5, 1-150

WeIDENREICH F., 1943, The skull of Sinanthropus pekinensis: a comparative study on a primitive hominid skull, Palaeontologia Sinica, New Series D, 10, 1-484
Weiner S., Q. Xu, P. GoldberG, J. Liu, O. BARYosEF, 1998, Evidence for the use of fire at Zhoukoudian, China, Science, 281, 251-253

Weiner S., Q. XU, P. GoldberG, J. LiU, O. BarYOSEF, 1999, Use of fire by humans: evidence from Layer 10 Locality 1 at Zhoukoudian, [in:] Book of abstracts of the International Symposium on Palaeoanthropology in Commemoration of the $70^{\text {th }}$ Anniversary of the Discovery of the First Skull of Peking Man at Zhoukoudian, 12-16 October 1999, Beijing, 103

Wolpoff M.H.,1996, Human Evolution (19961997 edition), McGraw-Hill Inc., New York

Wolpoff M.H., A.G. Thorne, J. JElineK, Y. ZHANG, 1994, A case for sinking Homo erectus - 100 years of Pithecanthropus is enough! Courier Forschungs-Institut Senckenberg, 171, 341-361

Wolpoff M.H., X. Wu, A.G. Thorne, 1984, Modern Homo sapiens origins: a general theory of hominid evolution involving the fossil evidence from East Asia, [in:] Origins of modern humans: a world survey of the fossil evidence, Smith F.R. \& Spencer F. (eds), Alan R, Liss, New York, 414-484

Woo J.K., L.P. CHIA, 1954, New discovery of a Sinanthropus pekinensis in Choukoutien, Acta Paleontol. Sinica, 2, 267-288

Woo J.K., T.K. CHAO, 1959, New discovery of a Sinanthropus mandible in Choukoutien, Paleovertebrata et Paleoanthropologia, 1, 155-158

Wu R., 1986,Chinese human fossils and the origin of Mongoloid racial group, Anthropos (Brno), 23, 151-155

Wu R., X. Dong, 1982, Preliminary study of Homo erectus remains from Hexian, Anhui, Acta Anthropol. Sinica, 1, 2-13

Wu R., M. Ren, X. ZHU, et al. (eds), 1985, Multidisciplinary study of the Peking Man Site at Zhoukoudian, Science Press, Beijing

Wu X., 1990, The evolution of humankind in China, Acta Anthropol. Sinica, 9, 312-321

Wu X., 1999, Investigating the possible use of fire at Zhoukoudian, China, Science, 283, 299

Wu X., F.E. POIRIER, 1995, Human evolution in China: a metric description of the fossils and a review of the sites, Oxford University Press, New York

XU S., 1986, Human fossils found at Qizianshan, Yiyuan County, Shandong, Acta Anthropol. Sinica, 5, 398-399 
ZDANSKY O., 1927, Preliminary notice on two teeth of a hominid from a cave in Chiihli (China), Bull. Geol. Soc. China, 5, 281-284

ZDANSKY O., 1952, A new tooth of Sinanthropus pekinensis Black, Acta Zoologica, 33, 189-191
ZHANG S., 1999, On the important advancement of the Paleolithic archaeology in China since 1949, Acta Anthropol. Sinica, 18, 183-214

ZuCKERMAN S., 1933, Sinanthropus and other fossil types, Eugenics Review, 24, 273-284

\section{Streszczenie}

„Człowiek pekiński” (zwany także sinantropem) ze stanowiska Zhoukoudian w Chinach jest jednym z najważniejszych znalezisk paleoantropologicznych XX wieku. Rozpoczyna się już osiemdziesiaty rok jego istnienia w nauce (pierwsze znalezisko z 1921 roku) i warto zastanowić się, jak zmieniły się nasze poglądy i jaki dokonał się postęp w badaniach szczątków tego człowieka i samego stanowiska Zhoukoudian, z którego pochodzi.

Davidson Black w 1927 roku nadał znalezisku nową nazwę rodzajową i gatunkową, Sinanthropus pekinensis, co oznacza „chiński człowiek z Pekinu”; od lat pięćdziesiątych włączony został do gatunku Homo erectus i pod taką nazwą naukową występuje do dzisiaj. Ostatnio jednak, pojawiają się propozycje [WOLPOFF et al. 1994], by włączyć gatunek $H$. erectus do ewolucyjnego gatunku $H$. sapiens, ponieważ nie ma pomiędzy nimi wyraźnej linii demarkacyjnej. Pozycja filogenetyczna $H$. erectus stała się punktem spornym dla zwolenników dwu odmiennych koncepcji pochodzenia anatomicznie współczesnego człowieka: koncepcji „multiregionalnej” i koncepcji wywodzącej go z Afryki (Out-of-Africa). Zwolennicy pierwszej uważają, że $H$. erectus jest bezpośrednim przodkiem $H$. sapiens, drugiej, że jest on boczną, bezpotomną gałęzią naszego drzewa rodowego. Dowody osteologiczne i archeologiczne z Chin zdecydowanie popierają ciagłość regionalną w ewolucji człowieka, a więc i multiregionalny model tej ewolucji.

Zbliżone do człowieka pekińskiego kopalne hominidy, znalezione we wschodnich Chinach, sugeruja, że w środkowym plejstocenie formy z tego kręgu szeroko i w sposób ciagły rozprzestrzenione były na obszarach od północnych Chin po dorzecze Jangcy. Datowanie stanowiska Zhoukoudian na 460 do 230 tys. lat temu, pochodzace $\mathrm{z}$ lat siedemdziesiątych, jest prawdopodobnie zbyt późne i ciagle trwają próby nowych oszacowań jego wieku. Wydaje się, że najmłodsi przedstawiciele tej formy pochodzą sprzed co najmniej 400 tys. lat. Liczne szczątki kopalnego człowieka, narzędzia, szczątki zwierzęce, warstwy popiołu, jak również pochodzące od hien koprolity świadczą o tym, że jaskinia Zhoukoudian w różnych czasach była schronieniem człowieka pekińskiego i hien. Grube warstwy popiołu, przepalona ziemia, kamienie, kości i nasiona, odkryte in situ w Zhoukoudian, zdecydowanie potwierdzaja, że człowiek pekiński posługiwał się ogniem. Warto dodać, że oprócz rekonstrukcji żeńskiej twarzoczaszki sinantropa, wykonanej w 1943 roku przez Weidenreicha i Swana, dysponujemy obecnie rekonstrukcją czaszki o twarzy męskiej autorstwa Tattersalla \& Sawyera (1996 r.).

Szczątki kostne wydobyte na stanowisku Zhoukoudian w latach 1927-1937 znikły w tajemniczych okolicznościach w trakcie inwazji japońskiej na Chiny w $1941 \mathrm{r}$. Ich poszukiwania trwają do dzisiaj. Po wojnie badania na stanowisku podejmowano w latach 1949, 1951, 195860, 1966, 1978-81, wydobywając: 6 izolowanych zębów, jedną żuchwę z zębami, dwa fragmenty czaszki i dwie fragmentaryczne kości długie. Znaleziska te znajdują się w cieszącej się zasłużoną sławą instytucji Instute of Vertebrate Paleontology and Paleoanthropology (IVPP), działającej w obrębie Chińskiej Akademii Nauk. Instytucja ta powstała z dawnej pracowni o nazwie Cenozoic Research Laboratory. Badania elektro-magnetyczne przeprowadzone na złożach stanowiska Zhoukoudian pozwalają spodziewać się obecności w nich dalszych szczątków człowieka pekińskiego. 
Począwszy od roku 1954, co pięć lat odbywają się sympozja upamiętniające odkrycie pierwszej czaszki człowieka pekińskiego przez W.C. Pei, co miało miejsce 2 grudnia 1929 r. W języku angielskim ukazały się dwie książki o podstawowym znaczeniu dla poznania historii człowieka pekińskiego: The Story of Peking Man, której autorami są Lanpo Jia i Weiwen Huang, oraz The Chronicle of Zhoukoudian (1927-1937), napisana przez Jia. W Internecie istnieją również strony (w języku chińskim) poświęcone historii odkryć, zespołu badawczego i najnowszych badań związanych z człowiekiem pekińskim oraz stanowiskiem Zhoukoudian. 